\title{
Integration of animal husbandry and nature conservation on grassland farms
}

\section{HERMANS ${ }^{1} \&$ P. VEREIJKEN ${ }^{2}$}

${ }^{1}$ Research Station for Cattle, Sheep and Horse Husbandry, Runderweg 6, NL 8219 PK Lelystad, Netherlands

${ }^{2}$ DLO-Centre for Agrobiological Research, P.O.Box 14, NL 6700 AA Wageningen, Netherlands

Received 24 May 1991; accepted 9 January 1992

\begin{abstract}
A farming model for peat grassland has been designed as an instrument in physical planning, integrating equally nature conservation and animal husbandry by combining the conditions for existence of both. It includes a subdivision of the farm in production grassland and nature grassland, such as marsh marigold hayfield and blue grassland. Each type of grassland has a suitable combination of groundwater level, $\mathrm{P}$ - and $\mathrm{N}$-controlled animal and plant production, and a regime of mowing and grazing depending on its function for flora, (avi)fauna and animal husbandry. Sixteen variants, differing in type of activity (dairy, suckler, sheep and cross-bred husbandry) and type of grassland, all single or in combination, are quantified. The initial results of modelling show that the integrated model offers various perspectives for physical planning aimed at integration of agriculture, nature and outdoor recreation. It concerns areas where production grassland has to be converted completely into nature grassland as part of the National Ecological Network, as well as areas where production grassland is partly to be maintained to serve dairy husbandry.
\end{abstract}

Keywords: physical planning, integrated farming, nature conservation, farm economy, peat grassland, $\mathrm{P}$ balance, dairy cows, suckler cows, sheep, cross-bred cattle.

\section{Introduction}

The Netherlands is a densely populated river delta, with growing contrasts between economic growth and urban expansion, on the one hand, and conservation of nature and environment on the other. As a consequence, physical planning is a permanent concern of national and regional authorities. Agriculture occupies more than $60 \%$ of the rural area. So a key issue of physical planning is segregation or integration of agriculture and the other functions of the rural area, such as nature conservation, groundwater protection and outdoor recreation. Of the 2 Mha of agricultural land, 1.1 Mha is grassland, and of that about 300000 ha is situated on peat soil. Subsequently, the peat grassland will be introduced in its former and present state, and the issue of segregation or integration will be related to the topic of this paper, an integrated farming model. 


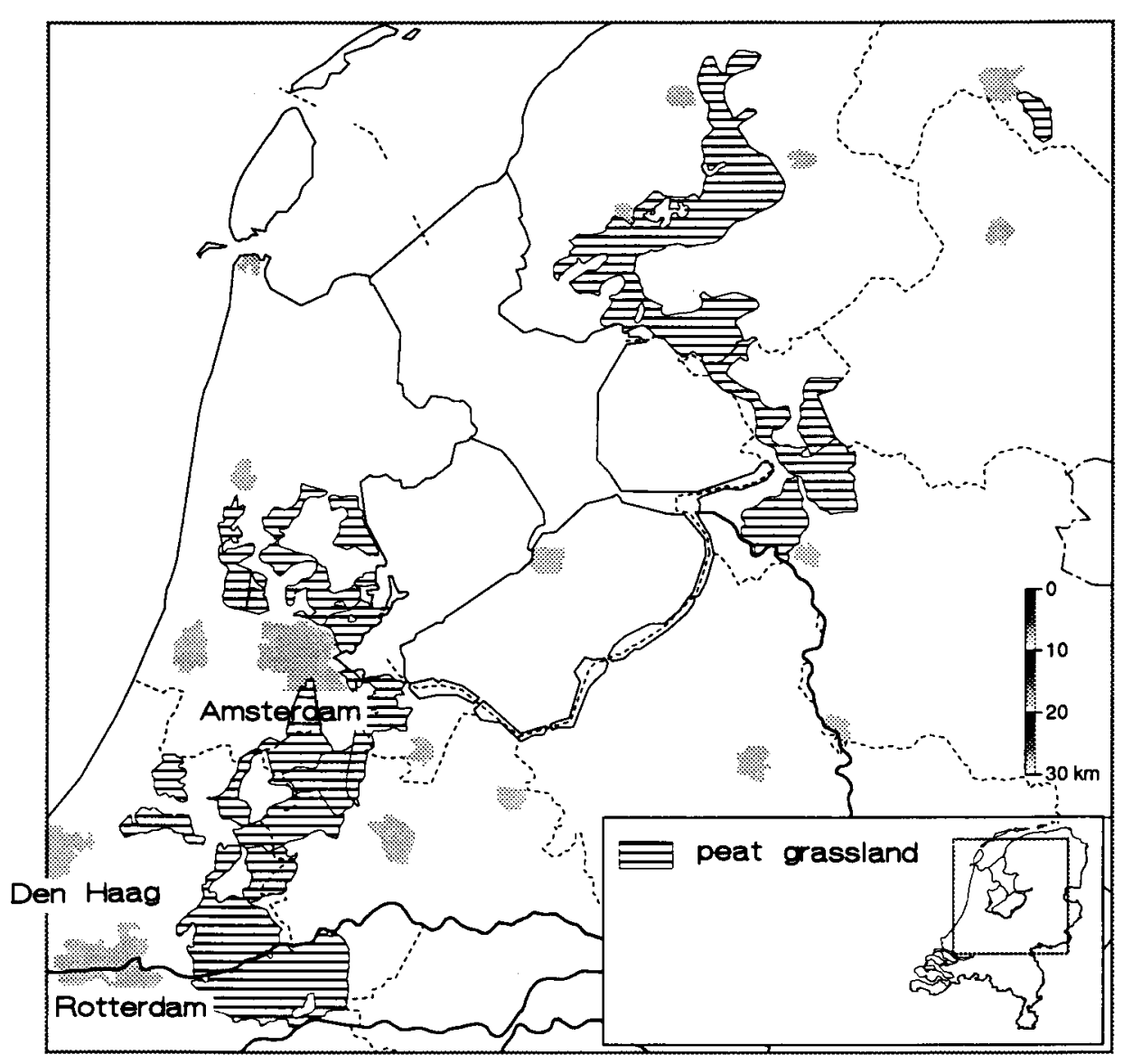

Fig. 1. Remaining peat grassland in the Netherlands (Source: Government Service for Land and Water Use).

\section{Peat grassland in its former state}

Peat grassland is the most characteristic historical element of Dutch landscape. It is mainly situated in the north and the west, in polders a few metres below sea level, reclaimed from A.D. 1000 onwards (Van der Linden, 1982) (Figure 1). Peat polders consist of long and narrow fields, intersected by an extensive web of ditches and canals. Usually, farm buildings and mills are situated at the periphery, along a dyke. The mills serve to pump up the precipitation surplus and inflowing water from the ditches in the wet centre of the polder into a canal or river. Due to centuries of drainage, the upper peat layer has shrank and decomposed, and as a result the soil level has subsided (Schothorst, 1982). Consequently, the soil has become too wet for arable farming, leaving dairy farming and sheep husbandry as the major farming activities during the last centuries. Traditionally, fields nearby the farm have been 
predominantly grazed. Most of the farm-yard manure has been applied here. It has resulted into species-poor grassland dominated by Lolium perenne (Poa-Lolietum). The less accessible inner parts of the polder have been predominantly mowed without being fertilized. It has brought about wet, species-rich grassland, such as marsh marigold hayfield (Calthion vegetation) and blue grassland (Cirsio-Molinietum). The consistent management of water and land has resulted into gradients of moisture and nutrients (notably phosphorus) between the centre and the periphery, with a rich and unique flora and fauna (De Boer, 1982; Westhoff et al., 1971). The populations of meadow birds, especially, have reached levels of European significance (Table 1).

Table 1. Current status of meadow birds breeding in the Netherlands between 1979-1987 and international importance of the Netherlands. (Source: Van Dijk et al., 1989).

\begin{tabular}{|c|c|c|}
\hline Species & $\begin{array}{l}\text { Breeding numbers } \\
(1979-1987)\end{array}$ & $\begin{array}{l}\text { Proportion of European } \\
\text { population breeding } \\
\text { in the Netherlands }(\%)\end{array}$ \\
\hline $\begin{array}{l}\text { Ruff } \\
\quad \text { Philomachus pugnax }\end{array}$ & $870-1050$ & 0.4 \\
\hline $\begin{array}{l}\text { Snipe } \\
\quad \text { Gallinago gallinago }\end{array}$ & $3900-\quad 4700$ & $0.7-0.9$ \\
\hline $\begin{array}{l}\text { Black-tailed Godwit } \\
\text { Limosa limosa }\end{array}$ & $78000-102000$ & $82-85$ \\
\hline $\begin{array}{l}\text { Redshank } \\
\quad \text { Tringa totanus }\end{array}$ & $25700-34000$ & $16-19$ \\
\hline $\begin{array}{l}\text { Oystercatcher } \\
\quad \text { Haematopus ostralegus }\end{array}$ & $88500-111000$ & $42-45$ \\
\hline $\begin{array}{l}\text { Lapwing } \\
\quad \text { Vanellus vanellus }\end{array}$ & $226000-278000$ & $24-28$ \\
\hline $\begin{array}{l}\text { Curlew } \\
\quad \text { Numerus arquata }\end{array}$ & $6900-8800$ & $5-6$ \\
\hline
\end{tabular}

\section{Peat grassland in its present state}

During the last decennia, the area of peat grassland has been greatly reduced by expansion of cities and industries, especially in the west (Figure 1). Besides, the management of the remaining peat grassland has been modernized drastically. Water-tables have been lowered to increase the bearing capacity of the soil and, consequently, the season for grazing and mowing. Subsequently, grassland productivity has been increased by higher inputs of fertilizers, and the vicinity of the world harbour of Rotterdam has been utilised to import large quantities of cheap concentrated feedstuffs. As a result, stocking rates could be increased considerably and income of farmers could keep pace with those in drier regions, notwithstanding the complicated and expensive management of water and grassland. However, this intensification of animal husbandry has flattened the gradients in water and grassland management, and as a result, the natural diversity (Anonymous, 1990; Egloff, 1986). 


\section{HERMANS AND P. VEREIJKEN}

\section{Segregation or integration of nature and animal husbandry?}

Currently, prices of milk and meat tend to fall because of ever-increasing production, compelling the European Community towards a market-oriented agricultural policy. Under these circumstances, most farmers in the peat area consider nature conservation claims less and less compatible with efficient and economic farm management, and thus as an aggravation of their struggle for life. So it seems logical to segregate nature from agriculture and to create nature reserves. However, costs of purchase and management are so high for the community that only a limited area can be conserved. A less radical and less expensive solution is financial compensation of farmers for losses due to restrictions of their management, such as postponed grazing and mowing in springtime and reduced fertilization. However, such management agreements cannot go further than safeguarding a part of the original flora and fauna in the margin of the enterprise.

Both solutions are considered in the National Environmental Policy Plan of the Netherlands (Anonymous, 1990). The plan aims at the rehabilitation and safeguarding of Dutch ecological values in a so-called national ecological network. The network consists of core areas, nature development areas and ecological corridors. Core areas are those with existing ecological values, nature development areas are aimed at future ecological values, and ecological corridors connect core areas and nature development areas. Considering the peat grassland, at the end of 1990, only some 9300 ha of the indicated 14000 ha has achieved the status of nature reserve, though most of it could not be purchased yet and has been put under a preliminary management agreement. These data illustrate the difficulty of safeguarding the ecological values of only $5 \%$ of the 300000 ha of peat grassland by physical planning based on segregation of agriculture and nature. Moreover, the success of nature conservation on such a small scale should be doubted, since intensive agriculture in the surrounding production areas has a strong influence on the abiotic conditions in the nature reserves. Nutrients penetrate the nature reserves through the atmosphere and surfacewater and groundwater and cause acidification and eutrophication.

Because of these major disadvantages of segregation, integration of animal husbandry and nature on a large scale is considered increasingly as a more sustainable solution. Another major reason to seek large-scale integration of nature and agriculture is to offer the people in the densely populated Netherlands a more diversified and attractive landscape for outdoor recreation (Figure 1). As a result, physical planning in the Netherlands is more and more aimed at maintaining at least existing ratios between rural and urban areas and integrating aims for nature and landscape conservation, nature-compatible outdoor recreation and urban development with industrial and agricultural activities. Consequently, the Government Service for Land and Water Use is increasingly changing over from land redevelopment for agriculture to multi-purpose land redevelopment. Therefore, it has commissioned the Research Station for Cattle, Sheep and Horse Husbandry to develop a farming model that integrates animal husbandry and nature interests on peat grassland. 
INTEGRATING ANIMAL HUSBANDRY AND NATURE

\section{Integrated farming model for peat grassland}

The farming model aims at the rehabilitation of the conditions of existence both of nature and farmers as equal partners. These conditions must be integrated in a balanced, non-conflictive way (Table 2).

Table 2. Conditions of existence of nature and farmers to be rehabilitated in an integrated farming model.

\begin{tabular}{ll}
\hline Nature & Farmers and employees \\
$\begin{array}{l}\text { Restoration of gradients in } \\
\text { moisture and nutrients }\end{array}$ & Healthy and respectable labour \\
$\begin{array}{l}\text { Restoration of the link between } \\
\text { plant- and animal production }\end{array}$ & Feasible and efficient management \\
$\begin{array}{l}\text { Minimum disturbance by man and } \\
\text { farm animals }\end{array}$ & $\begin{array}{l}\text { Sufficient size of the enterprise } \\
\text { to achieve a basic income at least }\end{array}$ \\
\hline
\end{tabular}

\section{Ecological objectives}

It includes returning to soil-borne animal production and to diversified land and water management in order to restore former moisture and nutrient gradients. Additionally, flora and fauna should be minimally disturbed by man and farm animals, especially in spring time. Associations of marsh marigold and blue grassland, including most species of meadow birds, only occur in oligotrophic, moist to wet habitats (CBS, 1987; Beintema, 1991). So both the original nutrient status of the soil and original groundwater levels should be restored (Van Strien \& Melman, 1987). The amount of available nitrogen $(\mathrm{N})$ may be controlled by a moderate input of fertilizers and a sufficiently high groundwater level, to moderate aeration and subsequent mineralization of the peat. Considering the P-AL count ( $m g \mathrm{P}_{2} \mathrm{O}_{5}$ per $100 \mathrm{~g}$ of soil), being the usual indicator for available $\mathrm{P}$ reserves in grassland, it is higher than 55 on one-third of the peat grassland (Figure 2). Such a high P-AL count is agronomically unnecessary (CAD-BWB, 1989) and ecologically unwanted, since P-AL should not exceed 29 for the marsh marigold association, and 18 for the blue grassland association (De Vries \& Kruijne, 1943; CBS, 1987). Consequently, the P-AL count of only $16 \%$ of the peat grassland is still appropriate for the marsh marigold association, and of only $3 \%$ for the blue grassland association (Figure 2). Therefore, all other grassland should be lowered in P-AL, insofar the former natural diversity is to be restored. It may be achieved by restricting the input and increasing the output of $\mathrm{P}$ until the desired level of P-AL has been reached. Contrary to $\mathrm{N}$, input and output of $P$ is easy to quantify because $P$ is not volatile and it is hardly soluble in water. Hence, it is hardly mobile in the soil, unless the soil is saturated. Moreover, $\mathrm{P}$ plays a dominant role in the eutrophication of surface waters, which make up almost $15 \%$ of the peat area. Therefore, the maintenance of an appropriate nutrient status of 


\section{HERMANS AND P. VEREIJKEN}

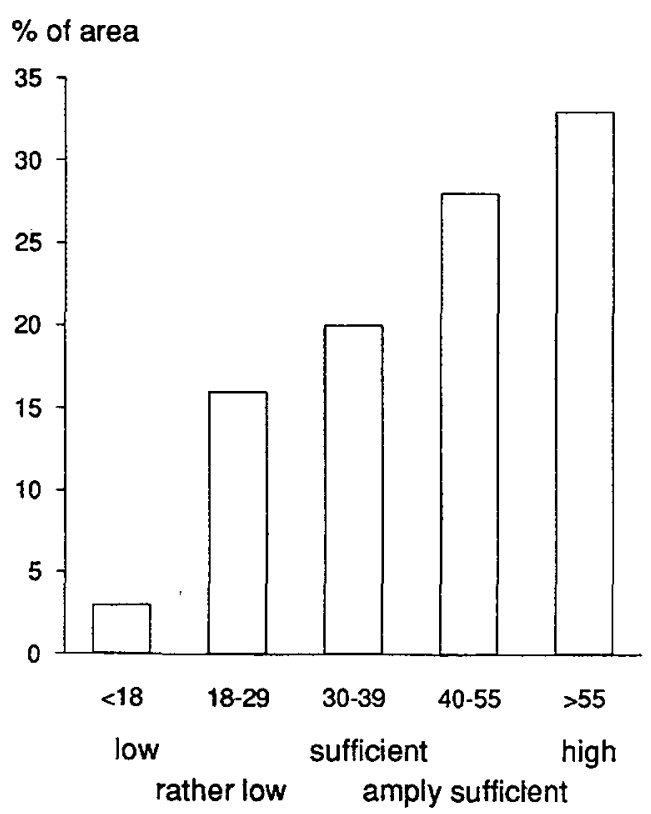

Fig. 2. P status of peat grassland 1988-1989 (Source: Analysis results from the Laboratory for Soil and Crop Testing, processed by the Netherlands Fertilizer Institute).

peat grassland can best be based on a balance between $\mathrm{P}$ input in feed and $\mathrm{P}$ output in milk and meat. $\mathrm{P}$ input in fertilizers is considered agronomically unnecessary and $\mathrm{P}$ output in farm-yard manure is considered ecologically unwanted, taking into account the high nutrient reserves in the Netherlands (unless the manure is processed and exported abroad, but this is very expensive).

The combination of $\mathrm{P}-\mathrm{AL}$ and $\mathrm{P}$ balance is also an effective instrument to restore the balance between plant and animal production. Namely, it limits stocking rates to the number of livestock units that can be fed on a hectare of grassland, supplemented by a limited amount of purchased feedstuffs $P$ equivalent to the output of milk and meat (Ecological Stocking Rate). It implies rehabilitation of the traditional grassland management aimed at self-sufficiency in feed for both summer and winter periods. As a result grazing will be less dominant on mowing, and flora and fauna will be less disturbed in spring since mowing cuts are usually older than grazing cuts. Besides, restoration of a high water-table and a low nutrient status of the soil will delay the start of the grazing and mowing season due to reduced bearing capacity of the soil and retarded grass growth. In this way the conditions of existence of flora and fauna of the peat grassland can be met sufficiently, since more than $90 \%$ of the characteristic species of marsh marigold hayfield and blue grassland flower in May or June (CBS, 1987) and meadow birds finish breeding and raising their young in the same period (Beintema, 1991). 


\section{Socio-economic objectives}

The integrated farming model should also meet the conditions of existence of farmers and their employees. Health and well-being of farmers requires healthy and respectable labour combined with a feasible and efficient management of the enterprise. Basic requirements to be mentioned are regular working hours and sufficient time off, housing of cattle in cubicles, year-round milking in a parlour, some welldrained grazing pastures close to farm buildings and mowing pastures sufficiently accessible for modern mechanization. Under Dutch conditions, full-time employment in animal husbandry entails about 2250 hours of labour annually. It corresponds to a herd size depending on the type of activity (dairy cows, beef cattle or sheep husbandry). The herd size corresponds with a farm size depending on the Ecological Stocking Rates, which in turn depend on the productivity of grassland and animals. Because Ecological Stocking Rates are much lower than current stocking rates, especially in case of beef production on nature grassland, the farm size should be increased considerably to maintain a basic income that meets current standards for farmers and their employees. Besides, extensification of the activities can be compensated for by premiums per hectare for nature conservation and, if possible, by premium prices for the products fulfilling 'organic' trade demands.

\section{Layout of the integrated farming model}

The conditions of existence of both nature and farmers can only be integrated in a non-conflictive way by subdividing a farm into production grassland and nature grassland, such as marsh marigold hayfield and/or blue grassland (Table 3). Production grassland is situated close to the farm buildings, entirely at the disposal of dairy husbandry. Marsh marigold hayfield and/or blue grassland is situated behind the production grassland, increasingly at the disposal of flora and fauna. Because of the low feeding value of the grass, marsh marigold hayfield is only used for beef and sheep husbandry. Blue grassland has such a poor production, that it may only serve as stable litter. The size of the production grassland and marsh marigold hayfield is tuned to the roughage requirement of the herd. The acreage of blue grassland is tuned to the litter requirement during the stable period. The subdivision of the farm implies a nutrient gradient lengthwise in the lots and ditches. The gradient is supported by drainage from the centrally-situated blue grassland and marsh marigold hayfield to the production grassland on the periphery. Thus, the conditions of existence of the aquatic part of the agro-ecosystem are restored, too.

\section{Variants of the integrated farming model}

The integrated farming model can widely be varied, according to type of activity and type of grassland, both single or in combination. Currently, 16 variants have been formulated (Table 4). The variants are based on the following assumptions.

Type of activities, single or combined. Dairy husbandry concerns Frisian cows of 600 


\section{HERMANS AND P. VEREIJKEN}

Table 3. Design, functions and management of the farming model integrating the conditions of existence of nature and farmers.

\begin{tabular}{|c|c|c|c|}
\hline \multirow[t]{3}{*}{ Design } & \multicolumn{3}{|c|}{ flows of water and nutrients } \\
\hline & & 1 & $\begin{array}{l}1 \\
1 \\
1\end{array}$ \\
\hline & $\begin{array}{l}\text { Production } \\
\text { grassland }\end{array}$ & $\begin{array}{l}\text { Marsh marigold } \\
\text { hayfield }\end{array}$ & Blue grassland \\
\hline \multicolumn{4}{|l|}{ Functions } \\
\hline flora & Poa-Lolietum & Calthion & Circio-Molinietum \\
\hline (avi)fauna & $\begin{array}{l}\text { food } \\
\text { biotope }\end{array}$ & $\begin{array}{l}\text { food and } \\
\text { breeding } \\
\text { biotope }\end{array}$ & $\begin{array}{l}\text { food and } \\
\text { breeding } \\
\text { biotope }\end{array}$ \\
\hline animal husbandry & dairy cattle & $\begin{array}{l}\text { beef cattle } \\
\text { and sheep }\end{array}$ & straw for stable \\
\hline \multicolumn{4}{|l|}{ Management } \\
\hline \multicolumn{4}{|c|}{ groundwater level (cm) } \\
\hline $\begin{array}{l}\max . \\
\min .\end{array}$ & $\begin{array}{l}25-40 \\
50-80\end{array}$ & $\begin{array}{l}<40 \\
50-80\end{array}$ & $\begin{array}{l}<40 \\
<50\end{array}$ \\
\hline $\begin{array}{l}\text { yield level } \\
\left(\mathrm{t} \mathrm{ha} \mathrm{a}^{-1} \mathrm{dm}\right)\end{array}$ & 12 & 6 & 4 \\
\hline $\begin{array}{l}\text { control of plant } \\
\text { production }\end{array}$ & $\max .200 \mathrm{~kg} \mathrm{ha}^{-1} \mathrm{~N}$ & organic manure & no manure \\
\hline $\begin{array}{l}\text { control of animal } \\
\text { production }\end{array}$ & $\mathbf{P}$ input $=\mathrm{P}_{\text {output }}{ }^{1}$ & $\mathbf{P}$ input $=\mathbf{P}$ output ${ }^{1}$ & $P$ input $=0$ \\
\hline number of cuts & unlimited & $\begin{array}{l}1 \text { mowing cut and } \\
\text { spring/autumn } \\
\text { grazing }\end{array}$ & 1 mowing cut \\
\hline first cut & unlimited & after 1 July & after 1 August \\
\hline
\end{tabular}

kg liveweight, producing 70001 milk per lactation (4\% fat), first calving at two years and replaced at 7 years, on average. All male and redundant female calves are sold at 7-10 days. Suckler husbandry concerns Charolais cows of $680 \mathrm{~kg}$ liveweight, first calving at three years and replaced at 6 years, on average. All male and redundant female calves are sold at weaning, after 7 months. Sheep husbandry concerns Texel ewes of $70 \mathrm{~kg}$ liveweight, 1.7 offspring per year and replaced at 6 years, on average. Husbandry of cross-bred cattle concerns Frisian $\times$ Piëmontese, $F_{1}$ heifers calving at 2.5 years. All $F_{2}$ calves ( $75 \%$ beef type) are sold at the age of $7-10$ days 
Table 4. Quantified 16 variants of the integrated farming model, in order of potential ecological value.

\begin{tabular}{|c|c|c|c|c|c|c|c|}
\hline \multirow{2}{*}{$\begin{array}{l}\text { Type of grass- } \\
\text { land }{ }^{1}, \text { single } \\
\text { or combined }\end{array}$} & \multirow{2}{*}{$\begin{array}{l}\text { Potential } \\
\text { ecological } \\
\text { value }^{2}\end{array}$} & \multicolumn{3}{|c|}{ Single activities } & \multicolumn{3}{|c|}{$\begin{array}{l}\text { Combined activities with } \\
\text { dairy cows (1.5 FWT) }\end{array}$} \\
\hline & & $\begin{array}{l}\text { dairy } \\
\text { cows } \\
2 \text { FTW }^{3}\end{array}$ & $\begin{array}{l}\text { suckler } \\
\text { cows } \\
2 \text { FTW }\end{array}$ & $\begin{array}{l}\text { sheep } \\
2 \text { FTW }\end{array}$ & $\begin{array}{l}\text { suckler } \\
\text { cows } \\
0.5 \text { FTW }\end{array}$ & $\begin{array}{l}\text { sheep } \\
0.5 \text { FTW }\end{array}$ & $\begin{array}{l}\text { cross-bred } \\
\text { cattle } \\
0.5 \text { FTW }\end{array}$ \\
\hline $\begin{array}{l}\text { pg (reference) } \\
\text { mh } \\
\text { pg - mh } \\
\text { pg } \quad-b g \\
\text { mh - bg } \\
\text { pg }-\mathrm{mh}-\mathrm{bg}\end{array}$ & $\begin{array}{l}1 \\
2 \\
3 \\
4 \\
5 \\
6\end{array}$ & $1 d$ & $\begin{array}{l}1 \mathrm{sc} \\
2 \mathrm{sc} \\
3 \mathrm{sc} \\
4 \mathrm{sc} \\
5 \mathrm{sc} \\
6 \mathrm{sc}\end{array}$ & $\begin{array}{l}1 s \\
2 s \\
3 s \\
4 s \\
5 s \\
6 s\end{array}$ & $2 \mathrm{dsc}$ & $2 \mathrm{ds}$ & $2 \mathrm{dc}$ \\
\hline
\end{tabular}

${ }^{1} \mathrm{pg}=$ production grasland, $\mathrm{mh}=$ marsh marigold hayfield, $\mathrm{bg}=$ blue grassland.

${ }^{2} 1=$ lowest and $6=$ highest potential ecological value ranking $\mathrm{pg}=1, \mathrm{mh}=2$ and $\mathrm{bg}=3$.

and $F_{1}$ heifers at $520 \mathrm{~kg}$, immediately after calving or some months later. All activities requires two full-time workers, considering both health and well-being of the workers and efficiency and continuity of the management. Combined activities exist of dairy farming requiring 1.5 full-time workers and a side-activity requiring 0.5 full-time workers.

Type of grasslands, single or combined. Production grassland is only considered in combination with nature grassland (beef or sheep husbandry as single activity or combined with dairy husbandry). Marsh marigold hayfield is considered single or in combination with blue grassland (beef or sheep husbandry as single activity). Dairy husbandry is not considered a viable activity on nature grassland, since the feed requirement of Dutch dairy cows with their current high milk-production capacity cannot be met under restricted input of concentrates according to a $\mathrm{P}$ balance.

\section{Quantification of variants}

Subsequently, size and composition of the herd, roughage requirement, production of the herd, size of the various types of grassland and economic results of the selected variants can be calculated (Figure 3). Size and composition of the herd is adjusted monthly depending on species specific management and rates of reproduction and mortality. Feed requirement in dry matter and energy is calculated monthly as the sum of the daily requirements per age class. Roughage production in dry matter and energy is calculated bimonthly based on a growth curve of the grass at standard usage. Herd production in terms of kilograms of milk, meat or wool is calculated monthly. Based on the total herd production per annum, the $\mathrm{P}$ output and the $\mathrm{P}$ equivalent purchase of concentrates is calculated. Subsequently, ultimate roughage production and ultimate size of the farm is determined. Finally, net operating result is 


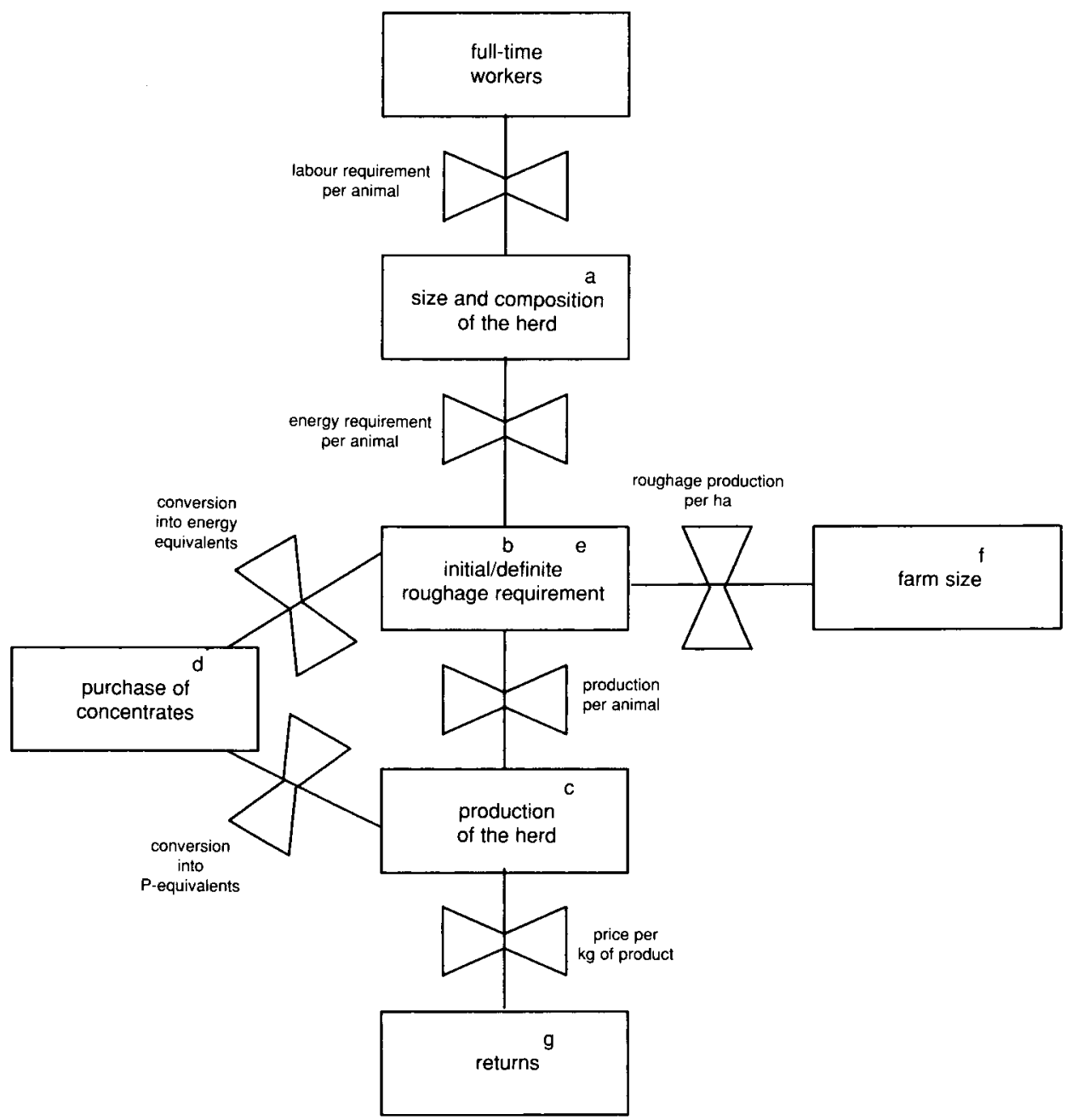

7 conversion variables to be fixed

$\square$ state variables to be calculated $(\mathrm{a}-\mathrm{g})$

Fig. 3. Quantification of the integrated farming model.

calculated, being the difference between all returns and all costs, including labour costs but excluding land taxes and rents. It is considered an indicator of the economic viability of the farm. In order to achieve a net operating result of zero at least, premiums per hectare can be determined to ensure the farmer and his employee basic incomes of NLG 65000 and NLG 58000 , respectively. 


\section{Initial results of modelling}

\section{Single activities}

The average dairy farm in the peat grassland area comprises 23 ha and 44 dairy cows, requiring a labour input of 1.2 full-time workers. In the integrated model, the scale of activities is considerably enlarged by subsequently increasing the number of full-time workers to 2.0, converting to Ecological Stocking Rates and nature grassland, and substituting dairy cattle by suckler cows or sheep (Table 5a). As a result, size of the reference dairy farm increases to 60 ha by increasing the labour input to 2.0 full-time workers and converting to Ecological Stocking Rates (reference 1d). Subsequent conversion to nature grassland and substitution of dairy cattle by sheep or suckler cows, eventually enlarges the scale to 165 and 440 hectares, respectively (variants $2 \mathrm{~s}-5 \mathrm{~s}$ and $2 \mathrm{sc}-5 \mathrm{sc}$ ). The average net operating result of dairy farms in the peat area between 1985 and 1989 was NLG 1220 per hectare, rent and additional costs of land excluded. As expected, the economic result of the reference dairy farm is comparatively higher because of its larger scale (1d). Complete substitution of dairy cows by sheep or suckler cows while maintaining production grassland would cause a dramatic fall of the economic result, notwithstanding a considerable scale

Table 5a. Farm size and net operating result of the single activities.

\begin{tabular}{|c|c|c|c|c|c|}
\hline \multirow[t]{2}{*}{ Variant } & \multicolumn{4}{|c|}{ Farm size (ha) } & \multirow{2}{*}{$\begin{array}{l}\text { Net operating result } \\
\left(\mathrm{NLG} \mathrm{ha} \mathrm{f}^{-1}\right)\end{array}$} \\
\hline & $\mathrm{pg}$ & $\mathrm{mh}$ & bg & total & \\
\hline $\begin{array}{l}\text { Dairy cattle } \\
\text { 1d (reference) }\end{array}$ & 60 & - & - & 60 & 2140 \\
\hline $\begin{array}{l}\text { Suckler cows } \\
1 \mathrm{sc} \text { (reference) } \\
2 \mathrm{sc} \\
3 \mathrm{sc} \\
4 \mathrm{sc} \\
5 \mathrm{sc} \\
6 \mathrm{sc}\end{array}$ & $\begin{array}{c}190 \\
- \\
<190 \\
185 \\
- \\
<185\end{array}$ & $\begin{array}{r}- \\
350 \\
<350 \\
- \\
330 \\
<330\end{array}$ & $\begin{array}{l}- \\
- \\
- \\
110 \\
110 \\
110\end{array}$ & $\begin{array}{c}190 \\
350 \\
190<\text { size }<350 \\
295 \\
440 \\
295<\text { size }<440\end{array}$ & $\begin{aligned}-1810 \\
-1000 \\
-1810<\text { result }<-1000 \\
-1290 \\
-700 \\
-1290<\text { result }<-700\end{aligned}$ \\
\hline $\begin{array}{l}\text { Sheep } \\
\text { 1s (reference) } \\
2 \mathrm{~s} \\
3 \mathrm{~s} \\
4 \mathrm{~s} \\
5 \mathrm{~s} \\
6 \mathrm{~s}\end{array}$ & $\begin{aligned} & 70 \\
&-- \\
&< 70 \\
& 65 \\
&- \\
&< 65\end{aligned}$ & $\begin{array}{c}- \\
125 \\
<125 \\
- \\
115 \\
<115\end{array}$ & $\begin{array}{l}- \\
- \\
- \\
50 \\
50 \\
50\end{array}$ & $\begin{array}{c}70 \\
125 \\
70<\text { size }<125 \\
110 \\
165 \\
115<\text { size }<165\end{array}$ & $\begin{aligned}-2570 \\
-1420 \\
-2570<\text { result }<-1420 \\
-1570 \\
-1070 \\
-1570<\text { result }<-1070\end{aligned}$ \\
\hline
\end{tabular}

$\mathrm{pg}=$ production grassland; $\mathrm{mh}=$ marsh marigold hayfield; $\mathrm{bg}=$ blue grassland.

Rent and additional costs of land excluded.

${ }^{2}$ Current prices are as follows (NLG): milk $0.73 \mathrm{I}^{-1}$, suckler cows $8.0 \mathrm{~kg}^{-1}$ slaughter weight, suckler calves $6.6 \mathrm{~kg}^{-1}$ liveweight, ewes, female lambs and male lambs $3.5,7.5$ and $8.0 \mathrm{~kg}^{-1}$ slaughter weight respectively, cross-bred cattle $7.0 \mathrm{~kg}^{-1}$ slaughter weight, cross-bred calves 835 per calf. 


\section{HERMANS AND P. VEREIJKEN}

enlargement (references $1 \mathrm{~s}$ and $1 \mathrm{sc}$ ). However, the negative economic results of single beef or sheep production activities can be alleviated considerably if production grassland is increasingly converted into nature grassland and the farm scale is correspondingly enlarged (variants $2 \mathrm{~s}-5 \mathrm{~s}$ and $2 \mathrm{sc}-5 \mathrm{sc}$ ). A major condition for existence (Table 2) of farmers and employees is a basic income of 65000 and 58000 guilders, respectively. To achieve this, the net operating result should be zero at least, excluding rent and additional costs of land. So, the negative net operating results per hectare of the variants indicate the minimally required premiums per hectare.

\section{Combined activities}

The assumed labour capacity of 1.5 full-time workers corresponds with a dairy farm of 40 ha and 70 cows, according to an Ecological Stocking Rate (Table 5b, reference). Its net operating result is still much more favourable than that of the current farm of 23 ha and 44 cows. In addition, side activities equivalent to 0.5 full-time workers will increase farm sizes from 40 to 105 (suckler cows), 65 (sheep) and 75 (cross-breds) ha respectively. All side activities have a negative net operating result, which can be met again by premiums per hectare if society is interested in the combination of food and nature production.

Table 5b. Farm size and net operating result of the combined activities.

\begin{tabular}{|c|c|c|c|c|c|}
\hline \multirow[t]{2}{*}{ Variant } & \multicolumn{4}{|c|}{ Farm size (ha) } & \multirow{2}{*}{$\begin{array}{l}\text { Net operating result } \\
\left(\mathrm{NLG} \mathrm{ha}^{1,2}\right)\end{array}$} \\
\hline & $\mathrm{pg}$ & $\mathrm{mh}$ & bg & total & \\
\hline $\begin{array}{l}\text { Main activity } \\
\text { Dairy cows } \\
\text { (reference) }\end{array}$ & 40 & - & - & 40 & 1450 \\
\hline $\begin{array}{l}\text { Side activity } \\
\text { Suckler cows } \\
\quad 2 \mathrm{dsc} \\
5 \mathrm{dsc}\end{array}$ & $\begin{array}{l}- \\
-\end{array}$ & $\begin{array}{l}50 \\
50\end{array}$ & - & $\begin{array}{l}50 \\
65\end{array}$ & $\begin{array}{l}-1120 \\
-\quad 940\end{array}$ \\
\hline $\begin{array}{l}\text { Sheep } \\
2 \mathrm{ds} \\
5 \mathrm{ds}\end{array}$ & $\begin{array}{l}- \\
-\end{array}$ & $\begin{array}{l}20 \\
20\end{array}$ & - & $\begin{array}{l}20 \\
25\end{array}$ & $\begin{array}{l}-1630 \\
-1240\end{array}$ \\
\hline $\begin{array}{l}\text { Cross-bred c } \\
2 \mathrm{dc} \\
5 \mathrm{dc}\end{array}$ & $\begin{array}{l}- \\
-\end{array}$ & $\begin{array}{l}25 \\
25\end{array}$ & $\overline{10}$ & $\begin{array}{l}25 \\
35\end{array}$ & $\begin{array}{l}-1240 \\
-1020\end{array}$ \\
\hline
\end{tabular}

$\mathrm{pg}=$ production grassland $\mathrm{mh}=$ marsh marigold hayfield; $\mathrm{bg}=$ blue grassland .

Rent and additional costs of land excluded.

${ }^{2}$ Current prices are as follows (NLG): milk $0.73 \mathrm{I}^{-1}$, suckler cows $8.0 \mathrm{~kg}^{-1}$ slaughter weight, suckler calves $6.6 \mathrm{~kg}^{-1}$ liveweight, ewes, female lambs and male lambs $3.5,7.5$ and $8.0 \mathrm{~kg}^{-1}$ slaughter weight respectively, cross-bred cattle $7.0 \mathrm{~kg}^{-1}$ slaughter weight, cross-bred calves 835 per calf. 
INTEGRATING ANIMAL HUSBANDRY AND NATURE

\section{Perspectives of the integrated farming model}

\section{Use in physical planning}

The initial results of modelling show that the integrated farming model for peat grassland can be used in various ways in physical planning aimed at integration of agriculture, nature and outdoor recreation. Firstly, it concerns areas where production grassland has to be converted completely into nature grassland, within the framework of the National Environmental Policy Plan. Here, variants of the integrated farming model with single activities of beef or sheep production can provide for the appropriate management of the nature grassland at minimum costs. As a first example, the Government Service for Land and Water Use has made a layout based on these variants for the 'Leekstermeer', a planned nature reserve of more than 1000 ha in the northern peat area. Secondly, the integrated farming model can also be used in areas where dairy husbandry is to be maintained in integration with nature conservation. Here, variants of the integrated farming model with beef or sheep production as a side activity allow conversion of production grassland into nature grassland to a large extent. Moreover, the side activities can provide for additional employment and income for the farmers remaining after extensification of the region. As a first example, 'Haren', a land redevelopment area of almost 3000 ha in the north, is currently being planned according to these variants. Five layouts are considered, with nature grassland varying from 30 to $70 \%$. Revision of farm size and type of activities following the integrated model is not included in a normal procedure of land redevelopment. As a result, integrated land redevelopment is more dependent on the willingness of farmers to cooperate. So an integrated plan should be made attractive enough both for remaining farmers to continue their activities and for surplus farmers to leave the region or to end their activities. It will be favoured by the existing tendency to scale up the activities in order to remain competitive on the international market.

\section{Further research}

To become a viable instrument for physical planning aimed at integration of agriculture and nature, the integrated farming model needs to be developed and evaluated under representative and well-controlled conditions. A first option is an experimental farm as for dairy farming and environment (Aarts et al., 1992). It allows a fundamental and systematic approach and it may provide a clear understanding of the underlying processes. Unfortunately, this does not hold for the influence of the farmer, which is known to be of vital significance for the success or failure of the system. Moreover, development of prototypes of so many variants on an experimental farm is expensive and time-consuming. The latter is a serious objection since there is an urgent need for integrated farming systems. Therefore, as a second option an experiment with pilot farms is more realistic. It allows scientists to cooperate with farmers and to differentiate between effects of systems, soils and management. As a result, it saves time combining the methodological steps of development, introduction and evaluation of prototype systems (Vereijken, 1992). Pilot farms may become 


\section{HERMANS AND P. VEREIJKEN}

available in land redevelopment areas where the integrated model is considered, such as 'Leekstermeer' and 'Haren'. A pilot project should include a sufficient number of farms to differentiate between effects of systems, soils and management. The economic evaluation of the farming model can be achieved in five to ten years. The ecological evaluation of the farming model will probably take several decennia of regular monitoring, since the creation of appropriate habitats and subsequent development of flora and fauna are long-term processes. So, general use of the farming model should rather be based on confidence than on hard scientific evidence!

\section{References}

Aarts, H.F.M., E.E. Biewinga \& H. van Keulen, 1992. Dairy farming systems based on efficient nutrient management. Netherlands Journal of Agricultural Science 40:285-299.

Anonymus, 1990. National Environmental Policy Plan of the Netherlands. Ministry of Housing, Physical Planning and Environment. SDU, The Hague, $103 \mathrm{pp}$.

Beintema, A.J., 1991. Breeding ecology of meadow birds (Charadriiformes); implications for conservation and management. Doctoral Thesis, University of Groningen, $127 \mathrm{pp}$.

CAD-BWB, 1989. Fertilization advice for grassland and feed crops. (In Dutch). Advisory Service for Soil, Water and Fertilization in Animal Husbandry, Wageningen, 72 pp.

CBS, 1987. Botanical database. (In Dutch). Netherlands Central Bureau of Statistics, Publication 103, Voorburg/Heerlen, $121 \mathrm{pp}$.

De Boer, Th.A., 1982. The use of peat soils for grassland. In: H. de Bakker \& M.W. van den Berg (Eds), Proceedings of the symposium on peat lands below sea level. International Institute for Land Reclamation and Irrigation, Wageningen. Publication 30, p. 214-221.

De Vries, D.M. \& A.A. Kruijne, 1943. On the preference of herbage plants for a number of plant nutrients. (In Dutch). Landbouwkundig Tijdschrift 55(673):83-92.

Egloff, B., 1986. Auswirkungen und Beseitigung von Düngungseinflüssen auf Streuwiesen. Thesis, University of Zürich, $183 \mathrm{pp}$.

Schothorst, C.J., 1982. Drainage and behaviour of peat soils. Report No. 3. Institute for Land and Water Management Research, Wageningen, 18 pp.

Van der Linden, H., 1982. History of the reclamation of the western fenlands and of the organizations to keep them drained. In: H. de Bakker \& M.W. van den Berg (Eds). Proceedings of the symposium on peat lands below sea level. International Institute for Land Reclamation and Irrigation, Wageningen. Publication 30:42-73.

Van Strien, A.J. \& Th.C.P. Melman, 1987. Effects of drainage on the botanical richness of peat grassland. Netherlands Journal of Agricultural Science 35:103-111.

Van Dijk, A.J., G. van Dijk, T. Piersma \& SOVON, 1989. Current estimates of meadow birds breeding in the Netherlands and their international significance. (In Dutch). Het Vogeljaar 37(2):60-68.

Vereijken, P., 1992. A methodic way to more sustainable farming systems. Netherlands Journal of Agricultural Science 40: 209-223.

Westhoff, V., P.A. Bakker, C.G. van Leeuwen \& E.E. van der Voo, 1971. Wild plants, flora and vegetation of Dutch nature reserves. Part II. (In Dutch). Society for Conservation of Nature Monuments in the Netherlands, 's-Graveland, 304 pp. 